\title{
KONFERENCJA OJCA MARCINA CHROSTOWSKIEGO WYGLOSZONA W OBOZIE W ROTHESAY. PRZYCZYNEK DO ŻYCIA RELIGIJNEGO OFICERÓW PRZEBYWAJĄCYCH NA WYSPIE BUTE ${ }^{1}$
}

STRESZCZENIE: Przedmiotem opracowania jest edycja źródła przybliżającego życie religijne oficerów Polskich Sił Zbrojnych na Zachodzie przebywających na wyspie Bute. Decyzją naczelnego wodza gen. Władysława Sikorskiego zlokalizowano tam Zgrupowanie Oficerów Nieprzydzielonych (Samodzielny Obóz Oficerski) Stacja Zborna Oficerów, do której kierowano zarówno oficerów starszych wiekiem nienadających się do służby liniowej, osoby skonfliktowane z przełożonymi jak również przeciwników politycznych gen. Sikorskiego. Wspomniany obóz funkcjonował od 1940 r. do 1944 r., przebywało w nim w tym okresie ponad 800 oficerów. Tematyka życia religijnego jest wzmiankowana jedynie na marginesie wspomnień pisanych w Rothesay. Szczęśliwie w spuściźnie dominikanina Marcina Chrostowskiego, który w 1940 r. pełnił obowiązki kapelana wspomnianej stacji zachował się tekst wygłoszonej przezeń konferencji religijnej. Warto wspomnieć, że ojciec Marcin przed wstąpieniem do zakonu uczestniczył jako ochotnik w kampanii 1920 r., walcząc z bolszewikami. W czasie II wojny światowej był między innymi kapelanem biskupa polowego Gawliny, z którym odbył podróż i wizytację oddziałów polskich w ZSRR. Następnie ojciec Marcin Chrostowski służył w szeregach 1. Dywizji Pancernej, jego bohaterska postawa została nagrodzona między innymi krzyżem Virtuti Militarii.

SLOWA KLUCZOWE: II wojna światowa, dominikanie, kazania, konferencje religijne,

Polskie Siły Zbrojne na Zachodzie, Zgrupowanie Oficerów Nieprzydzielonych.

\section{THE CONFERENCE OF FATHER MARCIN CHROSTOWSKI HELD IN THE CAMP OF ROTHESAY. A CONTRIBUTION TO RESEARCH ON RELIGIOUS LIFE OF OFFICERS ON THE ISLE OF BUTE}

ABSTRACT: The object of this paper is the edition of a textual source which shows religious life of the Polish Armed Forces in the West which were staying on the Isle of Bute. Commander-in-chief, general Władysław Sikorski decided that officers

1 Jestem winien gorące podziękowania za życzliwe i nader wnikliwe uwagi Panu dr. hab. Krzysztofowi Kaczmarskiemu, dzięki którym ustrzegłem się przed nieścisłościami i uproszczeniami w niniejszej pracy.

„Nasza Przeszłość” t. 134: 2020, s. 233-250. 
without allocation (Independent Officers' Camp), Officer Concentration Station, are to be placed there. Both elderly officers (incapable of liner service), people conflicted with superiors and political enemies of gen. Sikorski were directed to this station. This camp existed since 1940 till 1944. More than 800 officers were staying there at this time. Religious matters have been only marginally mentioned in recollections from Rothesay. Fortunately, in the legacy of father Marcin Chrostowski OP (who served as the station's chaplain) a text of his religious conference has been passed down to our day. It needs to be said that father Marcin volunteered in 1920 campaign against the Soviets, i.e. before he entered the Dominican order. During WWII he was (among his other tasks) a chaplain of the field bishop Gawlina with whom he went to visit Polish soldiers in USSR. Later, father Chrostowski served in the $1^{\text {st }}$ Armored Division. His heroism was rewarded (among other things) by the War Order of Virtuti Militari.

KEYWORDS: World War II, Dominicans, homilies, religious conferences, Polish Armed Forces in the West, Officers without allocation.

Translated by Dominik Jemielita

Dzieje Zgrupowania Oficerów Nieprzydzielonych/Samodzielnego Obozu Oficerskiego/Stacji Zbornej Oficerów budzą żywe zainteresowanie zarówno historyków jak i dziennikarzy ${ }^{2}$. Tak podsumował je jeden z oficerów przebywających w Rothesay: „Historia kilkuset oficerów, przeniesionych w stan nieczynny na obczyźnie pozostanie na zawsze osobliwością bez precedensu i oby bez dziedzictwa. Osobliwością naprawdę niepowtarzalną w naszych dziejach"3. Obóz w Rothe-

${ }^{2}$ Zob. przykładowo książkę przybliżającą losy wuja autorki Ignacego Raczkowskiego, na tej kanwie ukazany został zarówno obóz w Cerizay jak i Rothesay M. S z e j n e r t, Wyspa Węży, Kraków 2018. Wyczerpujący przegląd badań dotyczących obozów izolacyjnych wraz z edycją szeregu źródeł zawiera erudycyjna monografia pióra K. K a c z marski e g o Nie tylko Rothesay. Oficerskie obozy izolacyjne oraz obóz dyscyplinarny dla żotnierzy Polskich Sit Zbrojnych w Wielkiej Brytanii (1940-1943), Rzeszów-Warszawa 2020; temat ten został wcześniej poruszony w pracy K. K a c z m a r s k i, Nie tylko Rothesay. Oficerskie obozy izolacyjne oraz obóz dyscyplinarny dla żotnierzy Polskich Sit Zbrojnych w Wielkiej Brytanii (1940-1943), [w:] Studia $z$ dziejów Polskich Sił Zbrojnych na Zachodzie (1939-1947), red. P. C h m i e l c o w, K. A. Tr o chm a n, Rzeszów-Warszawa 2019, s. 51-93. Ponieważ szereg problemów został następnie poszerzony w książce tegoż autora poniżej cytowana będzie najnowsza monografia o tym samym tytule.

3 S. Mękarski, Zapiski z Rothesay 1940-1942, w opracowaniu redakcyjnym A. A d a m c z y k a, Londyn-Piotrków Trybunalski 2003, s. 437; niemal identycznie podsumował fakt istnienia obozów T. Münnich, Cerizay $i$ Rothesay, „Zeszyty Historyczne", 1986, z. 78, s. 229. 
say zlokalizowany na wyspie Bute u wybrzeży Szkocji bywał niesłusznie określany: „Wyspą wężów ${ }^{4}$, szkocką Berezą a nawet szkocką Wyspą Sołowiecką ${ }^{5}$ czy wyspą małpią" wyjazdów mieszkańców Glasgow nie było jednakże więzieniem, a jak to ujął przebywający tam jeden $\mathrm{z}$ oficerów ,(...) wyspą odosobnienia. Drutu kolczastego naokoło wyspy nie było. Ale była woda. Bez specjalnej przepustki od «dwójki»» obozowej nie sprzedawano biletu na przejazd poza wyspę. Bez pieczątki «dwójki» nie można było nadać telegramu. Listy oddawało się do cenzury. Poza tym warunki były doskonałe. Pobory, co prawda obcięte do połowy, wystarczały na opłacenie mieszkania, jedzenia i prania, na zakup papierosów i gazet, no i na małą czarną" była to „(...) składnica ludzi, którzy do niczego już się nie nadają" . O tym jak wielka przepaść dzieliła Rothesay od Berezy Kartuskiej

${ }^{4}$ Określenia tego użył w swych wspomnieniach S. Strumph W o j t k i e w i c z, Wbrew rozkazowi. Wspomnienia oficera prasowego 1939-1945, Warszawa 1979, s. 192.

${ }^{5}$ Zob. przykładowo W. D e c, Narwik i Falaise, Warszawa 1972, s. 166.

${ }^{6} \mathrm{R}$. U m i a s t o w s k i, Dziennik wojenny 18 IX 1939-19 IX 1945, wstęp i opracowanie P. M. Ż u k o w s k i, Warszawa 2009, s. 379. Odnośnie do czarnej legendy wyspy Bute zob. szerzej K. K a c z m a r s k i, Nie tylko Rothesay, s. 9, 174.

7 Byli to rezydenci Oddziału II sztabu Naczelnego Wodza - zob. A. A d a m c z y k, Wstęp, [w:] S. M ę k a r s k i, Zapiski z Rothesay 1940-1942, s. 8.

${ }^{8}$ W. D e c, Narwik i Falaise, s. 166; zob. też A. Majewski, Wojna, ludzie i medycyna, t. 1, Lublin 1960, s. 95; zob. też opinię dotyczącą inwigilacji w samym obozie R. U m i a s t o w s k i, Dziennik wojenny, s. 443; S. M ę k a r s k i, Zapiski z Rothesay, s. 81; por. wypowiedź podkreślającą dobre warunki lokalowe panujące w Rothesay L. C i o ł k o s z o w a, Spojrzenie wstecz, rozmowy przeprowadził A. F r i s z k e, Paris 1995, s. 169; S. M ę k a r s k i, Zapiski z Rothesay, s. 57-58, 472; zob. też przytoczoną przez Krzysztofa Kaczmarskiego wypowiedź z 16 sierpnia 1940 r. gen. Sikorskiego na posiedzeniu komisji wojskowej Rady Narodowej opisującą motywy założenia obozu w Rothesay oraz warunki tam panujące: „Jeśli chodzi o pomysł umieszczenia tych oficerów na wyspie, to miał on na celu wykluczenie zarzutu jakiegokolwiek prześladowania ich, a poza tym potrzebę izolowania ich od zdrowego elementu. Oficerowie ci - nawiasem mówiąc - mieszkają w dobrych warunkach w pensjonatach kąpieliska, do którego jeździli najbogatsi ludzie". Cyt. za K. K a c z marski, Nie tylko Rothesay, s. 36; zob. też M. D y m a r s k i, Polskie obozy odosobnienia we Francji $i$ w Wielkiej Brytanii w latach 1939-1942, „Dzieje Najnowsze”, R. 29: 1997, z. 3, s. 122-123. Odnośnie do przepustek, urlopów i inwigilacji zob. uwagi K. K a c z $\mathrm{m}$ a r s k i, Nie tylko Rothesay, s. 61, 63-68.

${ }^{9} \mathrm{~J}$. R o s t w o r o w s k i, Moje drogi wojenne. Wspomnienia oficera armii brytyjskiej. Szkocja-Afryka Zachodnia-Normandia-Holandia-Niemcy 1940-1945, wybór i oprac. Stanisław J. i Wojciech R o s t w o r o w s c y, Pruszków 2016, s. 15. 
najwymowniej świadczy fakt, że: „Dowódca polskiego zgrupowania na szkockiej wyspie zwrócił się do podległych sobie - do pewnego stopnia - oficerów polskich z «zaleceniem», ale nie rozkazem, żeby nie kupowali na własny użytek samochodów na raty" ". Stację Zborną Oficerów oficjalnie powołano 14 sierpnia 1940 r., aczkolwiek pierwsze kroki stworzenia miejsca, do którego można by skierować oficerów „niereprezentujących żadnych wartości bojowych” naczelny wódz gen. Władysław Sikorski zapowiedział już 26 czerwca 1940 r. Plan ten był następnie doprecyzowywany 11 i 18 lipca. 5 dni później generał ogłosił decyzję stworzenia miejsca, w którym oficerowie starsi wiekiem mogliby $\mathrm{w}$ jednym $\mathrm{z}$ miast szkockich oddawać się pracy nad wybranymi zagadnieniami z dziejów wojskowości, w szczególności mieli oni zająć się opracowywaniem doświadczeń wyniesionych z kampanii wrześniowej oraz zachodniej z Francji ${ }^{11}$. Warto podkreślić, że do obozu tego delegowano zarówno oficerów starszych wiekiem i nienadających się do służby wojskowej z powodów zdrowotnych ${ }^{12}$,

${ }^{10}$ C. J éśma n, Brytyjski eksperyment z Polakami, „Zeszyty Historyczne”, 1986, z. 76, s. 200; zob. też wzmiankę o napisaniu przez jednego z osadzonych pracy o Fryderyku Chopinie, która została następnie przetłumaczona na język angielski i ogłoszona drukiem w Glasgow w 1942, jako reakcja na przeświadczenie angielskiego małżeństwa o tym, że wielki kompozytor był Francuzem T. A l f - T a r c z y ń s k i, Wspomnienia oficera Pierwszej Brygady, Londyn 1979, s. 172-173; por. L. K a n i a, Dylematy wojskowej Temidy. Problemy orzecznicze sądów wojennych Polskich Sit Zbrojnych na Zachodzie w latach II wojny światowej, „Wojskowy Przegląd Prawniczy", 2014, nr 2, s. 12.

${ }^{11}$ K. K a c z m a r s k i, Nie tylko Rothesay, s. 9, 21-22, 29, 57, 174-177, aneks nr 3, 11 sierpnia 1940 r. Rozkaz dowódcy obozów i oddziałów WP w Szkocji gen. dyw. Mariana Kukiela o utworzeniu Zgrupowania Oficerów w Rothesay s. 217-220; J. Z u z i a k, ,Więźniowie” Sikorskiego - internowani w Cerizay, Rothesay i Tighnabruaich, „Acta Universitatis Lodziensis. Folia Historica”, 2019, t. 104, s. 174-175; patrz też wypowiedź gen. Sikorskiego z sierpnia 1940 r. objaśniająca motywację stworzenia ośrodka dla oficerów przytoczoną w pracy: M. K w i e c i e ń, Wśród potępieńczych swarów. Prawne aspekty rozliczeń politycznych wśród uchodźstwa polskiego we Francji i Wielkiej Brytanii 1939-1943, Kraków 2013, s. 352; zob. też M. D y m a r s k i, Polskie obozy odosobnienia we Francji $i$ w Wielkiej Brytanii, s. 121-124; T e n ż e, Stosunki wewnętrzne wśród polskiego wychodźstwa politycznego we Francji $i$ w Wielkiej Brytanii 1939-1945, Wrocław 1999, s. 120; J. Z u z i a k, Obozy izolacyjne Rothesay i Tignabruaich. Z historii Polskich Sit Zbrojnych w Wielkiej Brytanii, „Mars. Problematyka i Historia Wojskowości. Studia i Materiały”, 1995, t. 3, s. 75; A. A d a m c z y k, Wstęp, s. 7-8.

${ }^{12}$ Odnośnie do wieku oficerów, którzy nie otrzymali przydziału z powodu braku miejsc $\mathrm{w}$ formowanych oddziałach zob. uwagi W. L e it g e b e r, $W$ kwaterze praso- 
przeciwników politycznych jak i oficerów skonfliktowanych ze swoimi przełożonymi ${ }^{13}$. W początkowym okresie istnienia obozu zdarzały się nawet ewidentne pomyłki, gdy np. grupa oficerów zamiast na staż do oddziałów brytyjskich trafiła do Rothesay ${ }^{14}$. Do połowy listopada 1940 r., kiedy to utworzony został podobóz oficerski w Tighnabruaich (przemianowany w marcu 1941 r. na oddzielny Obóz Oficerski), w obozie w Rothesay przebywało również kilkudziesięciu oficerów, na których ciążyły różne zarzuty natury moralnej (przede wszystkim pijaństwo, ale także homoseksualizm) i przeciwko którym toczyły się postępowania przed sądami polowymi ${ }^{15}$.

Skupienie na wyspie Bute kilkuset polskich oficerów, którzy pozostawali zupełnie bezczynni, mieszkających w ,(..) mniej lub bardziej luksusowych pensjonatach i hotelach" ${ }^{16}$ w czasie, gdy ich brytyjscy koledzy walczyli z Niemcami, budziło zdziwienie społeczeństwa szkockiego. Stało się to nawet powodem interpelacji w Izbie Gmin posła Labour Party Adama McKinlaya oraz ministra spraw wewnętrznych Herberta Morrisona, który odwiedzając swoją siostrę

wej. Dziennik z lat wojny 1939-1945. Od Coëtquidan do „Rubensa”, London 1972, s. 85; por. M. K w i e c i e ń, Wśród potępieńczych swarów, s. 352-353.

13 S. M ę karsk i, Zapiski z Rothesay, s. 56; J. R o s tw or ow s k i, Moje drogi wojenne, s. 49; S. Strumph W ojtki e w i c z, Wbrew rozkazowi, s. 192; zob. też opinię A. N a r b u t t - Ł u c z y ń s k i e g o, U kresu wędrówki. Wspomnienia, Londyn 1966, s. 415; R. U m i a s t o w s k i, Dziennik wojenny, s. 228, 377, 384; M. F e 1 d h u z e n, Rubens miat filię w Szkocji, „Kultura”, 1953, nr 11 (73), s. 110; T. M ü n n i ch, Cerizay $i$ Rothesay, s. 227; C. J e śm a n, Brytyjski eksperyment, s. 200; L. M i t k i e w i c z, Z gen. Sikorskim na obczyźnie (fragmenty wspomnień), Paryż 1968, s. 97-98; zob. też opis groźby przeniesienia do obozu w Rothesay; T e n ż e, Rubens heroiczny, „Kultura”, 1953, nr 4 (66), s. 100; patrz szerzej rozdz. pt. Przyczyny umieszczania $w$ obozach izolacyjnych $\mathrm{M}$. K w i e c i eń, Wśród potęieńczych swarów, s. 356-362; M. D y m a r s k i, Stosunki wewnętrzne, s. 119-120; L. K a n i a, Dylematy wojskowej Temidy, s. 12; J. Z u z i a k, ,Więźniowie” Sikorskiego, s. 182183; K. K a c z m a r s k i, Nie tylko Rothesay, s. 40-48, 72-73, 173.

14 Zob. szerzej W. S z p a k o w i c z, Dzienniki cichociemnego 1939-1942, wstęp, opracowanie i redakcja K. K a c z m a r s k i, K. A. T o c h m a n, Rzeszów 2014, s. 190; A. A d a m c z y k, Wstęp, s. 8; K. K a c z m ars k i, Nie tylko Rothesay, s. 24 i n.; zob. też J. P i e tr z a k, ,Wyeliminowanie z szeregów elementu uciążliwego i niebezpiecznego”. Sprawa Obozu Dyscyplinarnego Armii Polskiej na Wschodzie w Latrum w Palestynie (1944-1945), „Dzieje najnowsze”, R. 47: 2015, z. 2, s. 79.

15 Zob. szerzej K. K a c z m a r s k i, Nie tylko Rothesay, s. 127-146.

${ }^{16} \mathrm{~S}$. M ę k ar s k i, Zapiski z Rothesay, s. 57-58. 
mieszkającą właśnie w Rothesay, był naocznym świadkiem opisywanych wydarzeń $^{17}$.

Sprawa stacji zbornej w Rothesay była również kilkakrotnie poruszana na forum Rady Narodowej RP. 13 lipca 1942 r. Rada Narodowa przyjęła uchwałę zalecająca „usunięcie” Stacji Zbornej z wyspy Bute i jej ,zreformowanie”. Ponowną rezolucję w tej sprawie Rada uchwaliła rok później (5 sierpnia 1943 r. $)^{18}$.

Od przełomu 1941/42 r. na mocy rozkazu gen. Sikorskiego oficerowie, którzy z racji wieku lub kategorii zdrowia byli niezdolni do służby wojskowej, lub nie mieli przydziału z powodu braku wolnych etatów, mogli zostać przeniesieni w stan nieczynny, względnie czasowo urlopowani. Tym samym umożliwiono im podjęcie pracy w zawodach cywilnych. Od tej pory liczba oficerów na wyspie Bute systematycznie malała ${ }^{19}$.

Jednak dopiero nowy naczelny wódz gen. Kazimierz Sosnkowski zdecydował się na podjęcie decydujących rozwiązań w sprawie przyszłości Stacji Zbornej Oficerów. 7 września 1943 r. minister obrony narodowej gen. Marian Kukiel wydał rozkaz zapowiadający likwidację stacji. Zgodnie z kolejnym rozkazem gen. Kukiela wydanym kilkanaście dni później, w miejsce Stacji Zbornej Oficerów miała zostać utworzona Kadra Ewidencyjna Oficerów. Pomimo zapewnień, że stacja ulegnie likwidacji do 15 listopada 1943 r., reorganizacja ta trwała do 1 stycznia 1944 r. Z tym dniem Stacja Zborna Oficerów w Rothesay została „przemianowana i przeorganizowana” w Kadrę Ewidencyjną Oficerów. Od chwili utworzenia w sierpniu 1940 r. do tego czasu przez Obóz/Stację Zborną przewinęło się około 800 oficerów ${ }^{20}$.

\footnotetext{
${ }^{17}$ M. K w i e c i e ń, Wśród potępieńczych swarów, s. 391; zob. też M. D y m a r s k i, Stosunki wewnętrzne, s. 121; K. K a c z m a r s k i, Nie tylko Rothesay, s. 94, 100 i n; Poland in the British Parliament 1939-1945, compiled and edited by W. J ę d r z e j e w c z, P. C. Ra m s e y, vol. II Fall 1941 - Spring 1944, New York 1959, nr 11, s. $42-45$.

${ }^{18} \mathrm{~K}$. K a c z m a r s k i, Nie tylko Rothesay, s. 107-112.

${ }_{19}$ M. K w i e c i én, Wśród potępieńczych swarów, s. 395-396; K. K a c z m a r s k i, Nie tylko Rothesay, s. 94-106.

${ }^{20}$ M. K w i e c i én, Wśród potępieńczych swarów, s. 399-403; K. K a c z m a r s k i, Nie tylko Rothesay, s. 107-125; L. K a n i a, Dylematy wojskowej Temidy, s. 12; J. Z u z i a k, „,Więźniowie” Sikorskiego, s. 189; zob. też L. M i t k i e w i c z, Z gen. Sikorskim, s. 99.
} 
Wśród ogłoszonych drukiem wspomnień czy opracowań, niejednokrotnie pojawia się wzmianka o pobycie w tejże placówce. Dysponujemy cennymi publikacjami przybliżającymi warunki i nastroje panujące na tej malowniczej wyspie - jak określił ją Janusz Meissner ${ }^{21}$. Wśród wydanych drukiem wspomnień opisujących warunki w jakich przebywali oficerowie, kwestia życia religijnego nie jest tematem zbyt często poruszanym. Najczęściej podkreśla się dojmujący brak zajęcia (z wyjątkiem doskonale zorganizowanych lekcji języka angielskiego ${ }^{22}$ ), opisywane są warunki panujące na wyspie i jej otoczeniu, wzmiankowany jest zakotwiczony w porcie HMS „Cyclopes”, do którego cumowały brytyjskie łodzie podwodne, wielokrotnie przewija się kwestia wynajmowanych pokoi w pensjonatach, a także przytaczana jest głośna sprawa aresztowania gen. Dąb-Biernackiego ${ }^{23}$.

${ }^{21}$ J. M e i s s n e r, Wspomnienia pilota. 3 Pióro ze skrzydel, Kraków 1985, s. 45.

${ }^{22}$ Wzmiankowane są także odczyty wygłaszane przez oficerów zob. przykładowo R. U mi a s t o w s k i, Dziennik wojenny, s. 67. Lekcje te we wspomnieniach jednego z uczestników określone zostały jako „bardzo przyjemne, zwłaszcza godziny o Anglii, ustroju, geografii, historii", tamże, s. 390; zob. też K. K a c zma r s ki, Nie tylko Rothesay, s. 53-54, 57-58.

${ }^{23}$ Istną kopalnią informacji o życiu w zgrupowaniu oficerów są wspomnienia Stefana Mękarskiego zob. S. M ę k a rs ki, Zapiski z Rothesay, s. 56 i n.; zob. też J. R o s tw or o w sk i, Moje drogi wojenne, s. 49-63, 70-77, 80; J. M e is s n e r, Wspomnienia pilota, s. 44-45, 52; W. D e c, Narwik i Falaise, s. 157-158, 165-166; J. G o d z i s z e w s k i, Zamiast postowia, [w:] T. G o d z i s z e w s k i, Pisane w Rothesay ze wspomnień oficera rezerwy, Warszawa 1973, s. 187-188; S. Strumph W oj tk i ew i cz, Wbrew rozkazowi, s. 192; W. L e i tg e b e r, W kwaterze prasowej, s. 151; R. U m i a s to w s k i, Dziennik wojenny, s. 378-384, 386-390, 396, 430-432, 437, 440-443, 446; S. S ę p - S z a r z y ń s k i, Trop legendy, „Kultura”, 1959, nr 9 (143), s. 112; K. M ün n i c h, List do redakcji, „Zeszyty Historyczne”, 1986, z. 78, s. 226; L. M i t k i e w i c z, Z gen. Sikorskim, s. 98; zob. też list skierowany do autorki pracy przybliżający życie codzienne oficerów na wyspie Bute oraz wypowiedzi mieszkańców wyspy w tym obszerne cytaty z wspomnień Stefana Mękarskiego: M. S z e j n e r t, Wyspa Węży, s. 44, 49-50, 84, 90-110, 112-116, 120-125, 128-134, $140,143-144,152-158,163,165-168,173-180,182-188,193-199,201-210$, 215220, 223, 230-231, 233-244, 248-250, 255-257, 280-282, 313, 321, 324. Spośród opracowań o „wyspie Węży” zob. szerzej uwagi o warunkach tam panujących M. Kwiecień, W'́ród potepieńczych swarów, s. 354-355, 368-370, 376-390; J. Z u zi a k, „Więźniowie” Sikorskiego, s. 178-179; wyczerpująco zagadnienie to zostało przedstawione w podrozdziale $\mathrm{nr} 3$ Warunki życia $w$ obozie $\mathrm{w}$ monografii K. K a c z m ar s k i, Nie tylko Rothesay, s. 48-75; zob. też Aneks nr 41940 sierpień 27, Rothesay - Plan pracy wyszkoleniowej w Zgrupowaniu Oficerów w Rothesay zatwierdzony przez jego dowódce gen. bryg. Bolesława Jacynę-Jatelnickiego, Aneks nr 5 
Aspekty życia religijnego osadzonych oficerów nigdy nie były tematem wiodącym wspomnień czy relacji z pobytu w Rothesay. Można odnaleźć pojedyncze wzmianki o uroczystościach religijnych, obchodach i przygotowaniach do świąt (Bożego Narodzenia ${ }^{24}$ czy Wielkanocnych ${ }^{25}$ ), pogrzebach ${ }^{26}$, nabożeństwach żałobnych ${ }^{27}$, próbach pozyskania członków do Sodalicji Mariańskieje ${ }^{28}$, a także opinie o mowach wygłaszanych przez księdza proboszcza ${ }^{29}$, staraniach księdza kapelana obozu Konstantego Pogłódka o wprowadzenie elementów liturgii typowej dla Polski w okresie Wielkanocy ${ }^{30}$; wszystkie te informacje umieszczane są na marginesie charakterystyki życia na wyspie Bute. Warto wspomnieć, że oficerowie ufundowali wizerunek Matki Boskiej Częstochowskiej do katolickiego kościoła pw. Świętego Andrze$\mathrm{ja}^{31}$. W tym celu w październiku 1940 r. powstał komitet, na którego czele stał gen. Mikołaj Osikowski. Obraz został namalowany przez ppłk. Zbigniewa Belinę-Prażmowskiego, do wzmiankowanej świątyni trafił na Wielkanoc 1941 r. $^{32}$. Na uwagę zasługuje też relacja Stefana

1940 listopad 7, Rothesay - Sprawozdanie z pracy kulturalnej w Samodzielnym Obozie Oficerskim w Rothesay za październik 1940 r. sporządzone przez komendanta obozu gen. bryg. Bolesława Jacynę-Jatelnickiego dla dowódcy I Korpusu (Samodzielny Referat Propagandy i Oświaty) K. K a c z m a r s k i, Nie tylko Rothesay, s. 227-237.

24 Odnośnie do przygotowań do świąt Bożego Narodzenia zob. szerzej uwagi o tym jak kucharze w hotelach, w których przebywali Polacy, 24 grudnia otrzymali wolne, aby tradycyjne potrawy mogli przygotować sami oficerowie M. S z e j n e r t, Wyspa Węży, s. 131.

25 S. M ę k a r s k i, Zapiski z Rothesay, s. 233-234; zob. też M. S z e j n e r t, Wyspa Węży, s. 167-168.

${ }^{26}$ Zob. szerzej opis pogrzebu wraz z krótką wzmianką o mowie wygłoszonej przez kapelana obozu w Rothesay S. Strumph W oj t k i e w i c z, Wbrew rozkazowi, s. 192-193.

27 Zob. wzmiankę o zorganizowanym nabożeństwie żałobnym za Kazimierza Bartla, a także w intencji aresztowanych lwowskich profesorów S. M ękarski, Zapiski $z$ Rothesay, s. 367.

${ }^{28}$ M. S z e j n e rt, Wyspa Węży, s. 115.

${ }^{29}$ R. U m i a s t o w s k i, Dziennik wojenny, s. 386.

30 S. M ę karski, Zapiski z Rothesay, s. 233; zob. też wzmiankę o kazaniach ks. Pogłdki, który „(...) jest bardzo oszczędny w organizowaniu wyobraźni kilkuset oficerów polskich", tamże, s. 95 (wpis z 2 listopada 1940 r.) oraz o kazaniu z dnia 3 sierpnia 1941 r., w którym ksiądz apelował, aby oficerowie nie krytykowali układu Sikorski-Majski, tamże, s. 350.

${ }^{31}$ S. M ę k a r s k i, Zapiski z Rothesay, s. 233; M. S z e j n e r t, Wyspa Węży, s. 100, 167. Odnośnie do samego obrazu zob. opis wraz ze zdjęciem tamże, s. 265-266.

${ }^{32}$ K. K a c z m a r s ki, Nie tylko Rothesay, s. 60. 
Mękarskiego z pobytu biskupa polowego Józefa Gawliny w Rothesay 8 października 1940 r. i 29 października 1941 r. $^{33}$.

Biorąc pod uwagę tak skąpe wzmianki źródłowe o życiu religijnym w obozie na wyspie Bute, znaczenie odpisu wygłoszonej konferencji religijnej w stacji zbornej jest nie do przecenienia. Została ona przygotowana i wygłoszona przez dominikanina Marcina Chrostowskiego. Przed wstąpieniem do zakonu braci kaznodziejów brał udział, jako ochotnik, w walkach z bolszewikami w 1920 r., po czym odbył studia na Wydziale Rolnym Szkoły Głównej Gospodarstwa Wiejskiego, wieńcząc je obroną dyplomową w 1926 roku $^{34}$. Następnie poszerzał swoją wiedzę początkowo $\mathrm{w}$ ramach stypendium a następnie jako asystent na Uniwersytecie Jagiellońskim, na którym też obronił pracę doktorską $^{35}$. Z zakonem braci kaznodziejów związał się w 1933 r. Wybuch II wojny światowej zastał go we Francji, gdzie zgłosił się w celu rozpoczęcia posługi jako kapelan pomocniczy Stacji Zbornej w Carpiagne. Po ewakuacji z Francji był kapelanem w Rothesay do września $1940 \mathrm{roku}^{36}$. Wspominając o postaci ojca Chrostowskiego należy wspomnieć, że był on kapelanem biskupa polowego, z którym udał się do ZSRR, by odbyć wizytację tworzącej się polskiej armii. Następnie przebywał na terenie Ziemi Świętej, skąd przeniesiony został do Anglii. Dalsze jego losy były związane z 9. Batalionem Strzelców Flandryjskich 1. Dywizji Pancernej. Jego bohaterska postawa (w czasie natarcia 3 października 1944 r. pod Baarle Nassan) została nagrodzona krzyżem Virtuti Militari. Co godne jest odnotowania nigdy nie afiszował się z faktem posiadania licznych odznaczeń, posiadał bowiem Krzyż Walecznych (odznaczony nim był dwukrotnie) oraz ordery brytyjskie i belgijskie ${ }^{37}$. Po zakończeniu II wojny światowej powrócił do kraju, czynnie angażował się zarówno w prace duszpasterstwa

\footnotetext{
${ }^{33} \mathrm{~S} . \mathrm{M}$ ę k a r s k i, Zapiski z Rothesay, s. 76-78, 393-394.

34 Archiwum Szkoły Głównej Gospodarstwa Wiejskiego w Warszawie, Akta studenckie, sygn. 1397/S. Indeks Studiów nr 1567; Zob. kopię dyplomu: Centralne Archiwum Wojskowe Wojskowego Biura Historycznego im. gen. broni Kazimierza Sosnkowskiego w Warszawie-Rembertowie, sygn. I.481.C.2564, k. 10 oraz Archiwum Uniwersytetu Jagiellońskiego, S II 619.

35 Archiwum UJ, WR 182, s. 13; Archiwum UJ, S II 524, nr 9328.

${ }^{36}$ Zob. szerzej K. K a c z m a r s k i, Nie tylko Rothesay, s. 60.

37 W. S z y m b or s ki, Życie $i$ działalność wojskowa o. Marcina Chrostowskiego uwagi wstepne, $\mathrm{w}$ druku.
} 
akademickiego w Poznaniu, duszpasterstwa chorych - jako kapelan Szpitala im. Franciszka Raszei w Poznaniu ${ }^{38}$. Ze stolicy Wielkopolski został przeniesiony po wygłoszeniu $\mathrm{z}$ ambony słów: „Ludzie nie przejmujcie się! Kościół przeżył Nerona, Kościół przeżył Hitlera, Kościół przeżyje Stalina" 39 . Przebywał następnie w licznych klasztorach (Wrocław, Jarosław, Prudnik, Gidle, Lublin, Święta Anna, Gdańsk, Poznań) aż w 1961 r., kiedy to udał się na misję do Australii, by pełnić obowiązki duszpasterza Polonii w parafii w Melbourne w Yarraville. Do kraju powrócił po zdiagnozowaniu śmiertelnej choroby, na krótko przed śmiercią w 1974 roku $^{40}$.

W spuściźnie o. Chrostowskiego wśród notatek, odpisów i odręcznie spisanych kazań znajduje się jedno kazanie wygłoszone 15 września 1940 r. w obozie w Rothesay ${ }^{41}$. Kapelan nawiązał w nim do encykliki papieża Piusa XII Summi pontificatus, do fragmentu poświęconego Rzeczypospolitej. W dalszej kolejności zaznaczył ważną rolę

${ }^{38}$ Biblioteka Konwentu oo. Dominikanów w Krakowie, Księga zmarlych członków Polskiej Prowincji Dominikanów (od roku 1900 do 1987), Warszawa 1987, sygn. B-3 1766, s. 82; Księga Zmarlych braci i ojców Polskiej Prowincji Zakonu Kaznodziejskiego czyli Dominikanów od 2 lipca 1927 roku, czyli od restaurowania polskiej prowincji, wyd. IV, Warszawa 2007, sygn. B-245595, s. 93; Ksiegga Zmartych braci i ojców Polskiej Prowincji Dominikanów pw. św. Jacka Odroważa od 2 lipca 1927 roku, czyli od restaurowania Polskiej Prowincji przez Generata Zakonu, Warszawa 2000, sygn. 34511 , s. 43.

${ }^{39}$ N. S z w e y c e r, Studenci pomagali studentom... „Caritas Academica” 1945-1948, [w:] Poznańscy dominikanie, Poznań 1997, s. 50.

${ }^{40}$ Odnośnie do literatury przybliżającej postać o. Chrostowskiego zob. szerzej: H. Gallus, E. Mikołajczak, Ojciec Marcin Chrostowski, Poznań 2001; Z. M a z u r OP, Chrostowski Marcin Bronistaw (1904-1974), dominikanin, kapelan wojskowy, [w:] Stownik polskich teologów katolickich 1918-1981, t. 5 a-j, red. L. Gr z e b i en SJ, Warszawa 1983, s. 213; C. J. W i c h r o w i c z OP, Stownik polskich pisarzy dominikańskich, Kraków 2012, mps, s. 93-94; B. S z w e d o, Zawsze w pierwszej linii. Kapłani odznaczeni Orderem Virtuti Militari 1914-1921, 1939 1945, słowo wstępne Ks. Bp Gen. Dyw. Sławoj Leszek Głódź Biskup Polowy Wojska Polskiego, Warszawa 2004, s. 25-28; T e n ż e, Kapelani wojskowi na drogach ku niepodległości. Sto biogramów na stulecie Biskupstwa Polowego w Polsce, słowo wstępne Ks. bp gen. bryg. J. Gu zdek Biskup Polowy Wojska Polskiego, Warszawa 2019, s. 65-70; T e n ż e, O. Marcin Chrostowski, dominikanin, doktor inżynier, kapelan w 1 Dywizji Pancernej, „Nasza Służba. Dwutygodnik Ordynariatu Polowego Wojska Polskiego", R. XXI: 2012, nr 10 (446), s. 11.

${ }^{41}$ Zostało ono zamieszczone w pracy W. S z y m bors ki, Sermons of Dominican Marcin Bronistaw Chrostowski Delivered during World War II, „Folia historica cracoviensia", 2020, t. 26, nr 2, s. 113-115. 
jaką pełniła Polska jako przedmurze chrześcijaństwa „przed zalewem wschodnich barbarzyńców". Przytoczył postaci bohaterskich dowódców, reprezentujących wysoki „stopień religijności”, takich jak: hetman Stanisław Żółkiewski, Jan III Sobieski, a nawet marszałek Józef Piłsudski orędownik kultu Matki Boskiej Ostrobramskiej. Stały się one kanwą do dalszych rozważań o losach żołnierzy rzuconych do Szkocji, o tym, że należy dbać o honor Polski i przyszłość Kościoła katolickiego w Szkocji. Dominikanin następnie nawoływał do dalszej intensywnej pracy nad „prawym charakterem” wzniesionym na zasadach „chrześcijańskiej katolickiej moralności”, a także przestrzegał przed udziałem w nabożeństwach protestanckich.

Kwestia pogłębiania wiedzy o religii, a co za tym idzie osobistej religijności została poruszona w poniższej konferencji religijnej, która także znajduje się w tej samej jednostce archiwalnej. Jest to maszynopiśmienny odpis wygłoszonej konferencji, został on zapewne sporządzony z oryginału podczas przygotowywania do druku biografii ojca Marcina Chrostowskiego przez Halinę Gallus i Eleonorę Mikołajczak. Rękopiśmienny oryginał nie zachował się. Warto nadmienić, że o. Chrostowski pełniąc posługę duszpasterską w Polskich Siłach Zbrojnych, starał się o podniesienie poziomu znajomości dziejów katolicyzmu w Szkocji, w tym celu ogłosił drukiem pracę z zakresu historii Kościoła katolickiego i szkockiego $^{42}$. Kwestia ta była przezeń także poruszana podczas konferencji religijnych wygłoszonych w Crawford ${ }^{43}$. Odczyty wygłaszane w tamtejszym obozie traktujące o różnicach pomiędzy katolicyzmem a anglikanizmem, zostały rozbudowane, uporządkowane i ogłoszone drukiem na łamach Nauki Chrystusowej. Aspekty konieczności pogłębiania osobistej religijności, a także wiedzy o religii były już poruszane w Rothesay.

\section{Edycja}

Podczas przygotowania edycji konferencji o. Chrostowskiego starano się uwzględnić zasady i postulaty zawarte w Materiatach do instrukcji wydawniczej dla źródet do dziejów najnowszych Polski, oprac. S. Kalabiński, F. Tych, Warszawa 1958 [maszynopis powielany], [w:] J. Tandecki, K. Kopiński, Edytorstwo źródet historycznych, War-

\footnotetext{
42 M. C h r o s t o w s k i, Kościól szkocki, „Nauka Chrystusowa”, R. II: 1941, z. 4 (kwiecień), s. 3-15, praca ta została wcześniej ogłoszona drukiem w czasopiśmie: „W Imię Boże", nr 3-5 zob. informacja zawarta na s. 15.

${ }^{43}$ Zob. wypowiedź nt. Co to jest kościół anglikański APPD, Ao 1514.
} 
szawa 2014, s. 413-447. Wedle postulatów znajdujących się w instrukcji uwspółcześniono pisownię i interpunkcję. Komentarze zostały zredukowane do skrótowych informacji o sygnalizowanych przez zakonnika encyklikach papieskich. W toku prac posługiwano się wydaniem Biblii opracowanym przez Komisję Przekładu Pisma Świętego, ogłoszonym drukiem przez Towarzystwo Biblijne w Polsce w Warszawie w $1996 \mathrm{r}$.

Archiwum Polskiej Prowincji Dominikanów w Krakowie

Spuścizna o. Marcina Chrostowskiego, sygnatura 1514

(brak paginacji jednostki), mps

Rothesay, 28 IX 1940 - Konferencja wstępna

I. Podziękowanie.

II. Nasza praca jest dużo wydajniejsza i owocniejsza jeżeli robimy ją z przekonaniem, z odczuciem potrzeby i znaczenia dla nas. Dlatego chciałbym zacząć tę naszą pierwszą konferencję wykazaniem konieczności zainteresowania się kwestiami teologicznomoralnymi i pogłębienia naszego religijnego wykształcenia.

Nauka nasza $\mathrm{w}$ gimnazjum była okresem nabywania wiadomości również w zakresie religii. Kolejno przechodziliśmy historię St.[arego] i N.[owego] Testamentu, historię Kościoła, dogmatykę, liturgikę i etykę. Ponieważ religia uważana jest za przedmiot łatwy, dobra ocena była zapewniona, więc na ogół nie poświęcaliśmy temu przedmiotowi większej uwagi. W każdym razie nasze wiadomości i wykształcenie religijne było na tym samym poziomie jak i ogólne $\mathrm{z}$ innych przedmiotów.

Co potem się stało? Zaczynaliśmy studia specjalne w wybranym zakresie, przez kilka lat nabywaliśmy zawodowe wykształcenie przede wszystkim, ale też i poziom naszych wiadomości podnosił się i rozszerzał na różne dziedziny wiedzy ludzkiej. Jednak czy to z braku wolnego czasu, bo pochłonięci byliśmy pracą zarobkową, życiem rodzinnym, czy też z leniwej niechęci, bo trochę się baliśmy konsekwencji, nasze wykształcenie religijne, już się od matury nie podnosiło, owszem siłą faktu szło w zapomnienie. I oto mamy niemal powszechny w naszej inteligencji, choć chwalebnych wyjątków zaczyna być coraz więcej, taki obraz powstałej dysproporcji, niewspółmierności wykształcenia zawodowego i ogólnego, słowem - świeckiego z religijnym. W muzeach medycyny patologicznej widzieć można zwierzęta, których jeden organ np. jakaś kończyna, zatrzymała się w rozwoju normalnym całego 
organizmu. Wówczas takie zwierzę robi, przez brak harmonii między poszczególnymi organami, przykre wrażenie.

Choć dla oka niewidoczne, jednak podobny obraz przedstawia nieraz stan umysłowy polskiego inteligenta: przy wysokiej nieraz ogólnej kulturze wielka ignorancja w kwestiach filozoficznych, teologicznych, moralnych. (Przykł. O. Gar.)

I sam zakres, i sposób przedstawienia, i nauki religii w szkole średniej jest dostosowany do poziomu umysłowego młodzieży szkolnej. Po wyjściu ze szkoły powstają nowe zagadnienia, trudności, wątpliwości. Umysł staje się więcej krytyczny, więcej ścisły. Dawniejsze wyjaśnienia, twierdzenia już nam nie wystarczają, wydają się nam zbyt naiwne, za mało naukowe. Zwłaszcza jeśli ktoś studiował nauki przyrodnicze, ten na pewno miał poważne trudności z kwestią pochodzenia człowieka, stosunku rozumu do wiary, posiadania rozumu przez zwierzęta itd. I nie jest to dla naszej wiary tak niebezpieczna prawdziwa nauka - poważna, ostrożna, pokorna, ile ta pseudonauka płytka, popularyzująca, błyskotliwa, zbyt pewna siebie, wychodząca z fałszywych założeń, obciążona pewnymi uprzedzeniami.

Ale nie tylko mamy trudności $\mathrm{z}$ religią wyniesioną $\mathrm{z}$ gimnazjum w dziedzinie intelektualnej, umysłowej.

Wiara narzuca nam pewien sposób życia, postępowania. Mówi nam o obowiązkach wobec Boga, bliźnich, samego siebie, wymaga pewnych praktyk religijnych przykrych dla naszej zepsutej przez grzech pierworodny natury, nakazuje wreszcie walkę ze złymi skłonnościami, przywiązaniami. A poza tym żyjąc na świecie ulegamy wpływom dobrym, ale także i złym. Widzimy naokoło dużo zła, brudu, przykładów życia ułatwianego, bez skrupułów. Z boleścią widzimy nieraz, że ludzie uczciwi są spychani, lekceważeni, a nieuczciwi nie tylko żyją spokojnie, ale mają stanowiska, zaszczyty, władzę.

I tu znowu często może się okazać, że nasza etyka narażona jest na wielkie próby i walki, bo w szkole za słabe położyliśmy fundamenty, bo zasady wiary, moralności Chrystusowej nie zapadły głęboko w nasze dusze.

Trzeba doprawdy być mocno w wierze utwierdzonym, a przez to mieć dostęp do źródła łask i sił, aby iść prostą drogą przez życie. To utwierdzenie, wytrwanie w wierze jest wtedy możliwe, jeśli jesteśmy 
do głębi przekonani o wyłącznej prawdziwości naszej religii, o jej pochodzeniu Boskim. Jak św. Paweł mówi: „Wiem, komu uwierzyłem”44.

Nie możemy kochać naprawdę naszej religii, Jej Założyciela, Kościoła, którzy przedłuża w czasie Chrystusa, jeśli nie znamy dostatecznie tych prawd. Wiara nie jest uczuciem, ale aktem rozumu. Jest to podstawowe prawo psychologiczne, że pożądanie idzie za poznaniem. Wola dąży do tego, co jej rozum przedstawia jako dobro. Teza o konieczności nabycia gruntowniejszego wykształcenia religijnego jest prawdziwa i słuszna nie tylko jeśli chodzi o życie osobiste, o zachowanie przez całe życie swej wiary, i w ten sposób osiągnięcie celu naszego na ziemi, to jest zbawienia duszy, ale także z uwagi, że każdy katolik inteligentny ma być apostołem tej wiary w swoim otoczeniu.

Pamiętajmy, że cel osobisty naszego życia - zbawienie duszy osiągamy nie w jakiejś izolacji, odosobnieniu pustelnika, ale współżyjąc z innymi, prowadząc życie społeczne, służąc swemu narodowi i państwu. Pełny rozwój osobowości możliwy jest w społeczeństwie, chociaż zawsze nie osoba ludzka jest dla społeczeństwa, ale społeczeństwo dla człowieka. Religia nie jest sprawą czysto prywatną, sprawą osobistego stosunku danego człowieka do Boga. Zasady religii muszą być respektowane w życiu rodzinnym, publicznym, państwowym. Nie chodzi tu oczywiście o to, by religia miała się mieszać do spraw czysto ziemskich. To należy do państwa. Ale Kościół zabiera głos i wydaje swoje sądy i wskazówki w dziedzinach mieszanych, złączonych ze sprawami duchowymi jak np. wychowanie młodzieży, które jednocześnie należy do rodziców, Kościoła i państwa. Sprawy społeczne, np. prawo własności, podział dóbr, wysokość zarobków, religię żywo interesują, o ile chodzi o zachowanie sprawiedliwości, danie możliwości robotnikom zaspokojenia wszelkich potrzeb materialnych i duchowych, Kościół jest żywo zainteresowany, aby jak najmniej było ludzi żyjących w nędzy, niezadowolonych, rozgoryczonych, bo takie warunki życia także niezmiernie utrudniają życie rodzinne, uczciwe, religijne. Religia przypomina obowiązki i prawa bogatym i biednym. Dlatego Kościół, przerabiając ludzi wewnętrznie, wpływa uzdrawiająco na życie społeczne, gospodarcze.

W ogóle, jeśli porównamy różne teorie, doktryny, systemy czy to filozoficzne, czy społeczne z nauką Kościoła o tych sprawach, jeśli

${ }^{44}$ Drugi list św. Pawła do Tymoteusza, rozdz. 1, 12. 
chodzi o kwestie, w których religia ma coś do powiedzenia, to znaleźlibyśmy stosunek części do całości. Znaczy to, że w każdej teorii, np. czy to w komunizmie, czy socjalizmie, czy liberalizmie i kapitalizmie, jest część prawdy, zmieszanej z fałszem i błędem. Jest to stanowisko jednostronne, ciasne, cząstkowe, skrajne. Nauka Kościoła jest całkowita, pełna, oparta na zdrowym rozumie, prawie naturalnym. Prawda ma się jakby środek, szczyt, wobec przeciwnych sobie błędów. Jakby szczyt góry ponad błądzeniem błędów powstających z niższego, częściowego poznania. Kościół może się zdobyć na sąd obiektywny. Zajmując wyższy punkt widzenia rzeczy ziemskich, ma dość odwagi, by mówić nieprzyjemną prawdę jednej i drugiej stronie. Prześladowania jako takiego nie pragnie, ale jeśli trzeba, przyjmie je, aby się swej misji prowadzenia ludzkości do Boga, nie sprzeniewierzyć.

Na katolików więc spada wielkie zadanie współpracy z Kościołem, aby to życie społeczne było budowane na zdrowych, słusznych, prawdziwych zasadach i prawach chrześcijańskich. Jest to właśnie cel Akcji Katolickiej - pomoc, apostolstwo ludzi świeckich pod kierunkiem hierarchii kościelnej.

Do takiej pracy apostolskiej, tak ważnej i zasługującej, trzeba dużo ludzi dobrej woli, ale też i dobrej głowy. Nie wystarczy sama chęć. Trzeba tu mieć pewne przygotowanie, znajomość nauki społecznej Kościoła. Zwłaszcza konieczne jest poznanie encyklik Ojca św. Piusa XI o sprawach społecznych - małżeństwie ${ }^{45}$, wychowaniu młodzieży ${ }^{46}$, komunizmie $^{47}$, hitleryzmie ${ }^{48}$. W ostatniej encyklice Piusa XII znajduje się też dużo głębokich myśli o totalistycznych zakusach współczesnych państw.

Zauważmy na zakończenie, że w Polsce czeka nas praca przeogromna we wszelkich dziedzinach. Znajdziemy się w tym smutnym, ale poniekąd szczęśliwym położeniu, że będzie można budowę zaczynać od fundamentów. A kładzenie fundamentów to dzieło bardzo ważne i odpowiedzialne wobec przyszłości, dlatego musimy te podstawy dać mocne, zdrowe, czyste - bo tylko na takim podkładzie przyszła Polska będzie wielka, potężna, groźna dla wrogów, dobra dla swoich dzieci. Polska godna nazwy królestwa Maryi, Matki Bożej i naszej.

\footnotetext{
${ }^{45}$ Encyklika Casti connubii z 31 grudnia $1930 \mathrm{r}$.

46 Encyklika Divini Illius Magistri z 31 grudnia 1929 r. oraz encyklika Non Abbiamo Bisogno z 29 czerwca 1931 r.

${ }^{47}$ Encyklika Divini Redemptoris z 19 marca 1937 r.

${ }^{48}$ Encyklika Mit brennender Sorge z 14 marca 1937 r.
} 


\section{BIBLIOGRAFIA}

\section{Źródla archiwalne}

Archiwum Polskiej Prowincji Dominikanów w Krakowie

Ao 1514 Kazania O. Marcina Chrostowskiego, 1943-1972 i b.d.

Archiwum Szkoły Glównej Gospodarstwa Wiejskiego w Warszawie

Akta studenckie, sygn. 1397/S.

Archiwum Uniwersytetu Jagiellońskiego

- WR 182.

- S II 524, nr 9328.

Centralne Archiwum Wojskowe Wojskowego Biura Historycznego im. gen. broni Kazimierza Sosnkowskiego w Warszawie-Rembertowie Kolekcja Akt Personalnych i Odznaczeniowych:

- sygn. I.481.C.2564 Chrostowski Bronisław Adolf, stopień ppor. pos. rusz.

\section{Biblioteka Konwentu oo. Dominikanów w Krakowie}

Księga zmartych członków Polskiej Prowincji Dominikanów (od roku 1900 do 1987), Warszawa 1987, sygn. B-3 1766.

Księga Zmarlych braci i ojców Polskiej Prowincji Zakonu Kaznodziejskiego czyli Dominikanów od 2 lipca 1927 roku, czyli od restaurowania polskiej prowincji, wyd. IV, Warszawa 2007, sygn. B-245595.

Księga Zmarlych braci i ojców Polskiej Prowincji Dominikanów p.w. św. Jacka Odroważa od 2 lipca 1927 roku, czyli od restaurowania Polskiej Prowincji przez Generała Zakonu, Warszawa 2000, sygn. 34511.

\section{Źródła drukowane}

Poland in the British Parliament 1939-1945, compiled and edited by Wacław Jędrzejewcz, Pauline C. Ramsey, vol. II Fall 1941 - Spring 1944, New York 1959.

Chrostowski M., Kościół szkocki, „Nauka Chrystusowa”, R. II: 1941, z. 4 (kwiecień), s. 3-15.

\section{Wspomnienia}

Alf-Tarczyński T., Wspomnienia oficera Pierwszej Brygady, Londyn 1979.

Ciołkoszowa L., Spojrzenie wstecz, rozm. A. Friszke, Paris 1995.

Dec W., Narwik i Falaise, Warszawa 1972

Feldhuzen M., Rubens miat filię w Szkocji, „Kultura”, 1953, nr 11 (73), s. $105-119$.

Godziszewski J., Zamiast postowia, [w:] T. Godziszewski, Pisane w Rothesay ze wspomnień oficera rezerwy, Warszawa 1973, s. 178-195.

Jeśman C., Rubens heroiczny, „Kultura”, 1953, nr 4 (66), s. 72-107. 
Leitgeber W., W kwaterze prasowej. Dziennik z lat wojny 1939-1945. Od Coëtquidan do „Rubensa”, London 1972.

Majewski A., Wojna, ludzie i medycyna, t. 1, Lublin 1960.

Meissner J., Wspomnienia pilota. 3 Pióro ze skrzydet, Kraków 1985.

Mękarski S., Zapiski z Rothesay 1940-1942, red. A. Adamczyk, LondynPiotrków Trybunalski 2003.

Mitkiewicz L., Z gen. Sikorskim na obczyźnie (fragmenty wspomnień), Paryż 1968.

Münnich T., Cerizay i Rothesay , „Zeszyty Historyczne”, 1986, z. 78, s. 226-229.

Narbutt-Łuczyński A., U kresu wędrówki. Wspomnienia, Londyn 1966.

Rostworowski J., Moje drogi wojenne. Wspomnienia oficera armii brytyjskiej. Szkocja-Afryka Zachodnia-Normandia-Holandia-Niemcy 1940-1945, oprac. S. J. i W. Rostworowscy, Pruszków 2016.

Sęp-Szarzyński S., Trop legendy, „Kultura”, 1959, nr 9 (143), s. 87-116.

Skowronek A., List do redakcji, „Kultura”, 1954, nr 6 (80), s. 154-156.

Strumph W. S., Wbrew rozkazowi. Wspomnienia oficera prasowego 19391945, Warszawa 1979.

Szpakowicz W., Dzienniki cichociemnego 1939-1942, red. K. Kaczmarski, K. A. Tochman, Rzeszów 2014.

Umiastowski R., Dziennik wojenny 18 IX 1939-19 IX 1945, oprac. P. M. Żukowski, Warszawa 2009.

\section{Opracowania}

Dymarski M., Polskie obozy odosobnienia we Francji $i$ w Wielkiej Brytanii w latach 1939-1942, „Dzieje najnowsze”, R. 29: 1997, z. 3, s. 113-127.

Dymarski M., Stosunki wewnętrzne wśród polskiego wychodźstwa politycznego we Francji i w Wielkiej Brytanii 1939-1945, Wrocław 1999.

Gallus H., Mikołajczak E., Ojciec Marcin Chrostowski, Poznań 2001.

Jeśman C., Brytyjski eksperyment z Polakami, „Zeszyty Historyczne”, 1986, z. 76, s. 198-205.

Kaczmarski K., Nie tylko Rothesay. Oficerskie obozy izolacyjne oraz obóz dyscyplinarny dla żotnierzy Polskich Sit Zbrojnych $w$ Wielkiej Brytanii (1940-1943), Rzeszów-Warszawa 2020.

Kaczmarski K., Nie tylko Rothesay. Oficerskie obozy izolacyjne oraz obóz dyscyplinarny dla żotnierzy Polskich Sit Zbrojnych $w$ Wielkiej Brytanii (1940-1943), [w:] Studia z dziejów Polskich Sit Zbrojnych na Zachodzie (1939-1947), red. P. Chmielcow, K. A. Trochman, Rzeszów-Warszawa 2019, s. 51-117.

Kania L., Dylematy wojskowej Temidy. Problemy orzecznicze sąów wojennych Polskich Sit Zbrojnych na Zachodzie w latach II wojny światowej, „Wojskowy Przegląd Prawniczy”, 2014, nr 2, s. 1-26. 
Kania L., Stużba sprawiedliwości Wojska Polskiego we Francji $i w$ Wielkiej Brytanii (październik 1939-październik 1940), „Przegląd HistorycznoWojskowy", 2014, t. 15 (66), nr 1 (247), s. 67-96.

Kwiecień M., Wśród potępieńczych swarów. Prawne aspekty rozliczeń politycznych wśród uchodźstwa polskiego we Francji $i$ Wielkiej Brytanii 1939-1943, Kraków 2013.

Mazur Z., Chrostowski Marcin Bronistaw (1904-1974), dominikanin, kapelan wojskowy, [w:] Stownik polskich teologów katolickich 1918-1981, t. 5 a-j, red. L. Grzebień, Warszawa 1983, s. 213-214.

Münnich K.., List do redakcji, ,Zeszyty Historyczne”, 1986, z. 78, s. 226.

Pietrzak J., ,Wyeliminowanie z szeregów elementu uciążliwego i niebezpiecznego". Sprawa Obozu Dyscyplinarnego Armii Polskiej na Wschodzie $w$ Latrum w Palestynie (1944-1945), „Dzieje najnowsze”, R. 47: 2015, z. 2, s. 79-91

Szejnert M., Wyspa Węży, Kraków 2018.

Szwedo B., Kapelani wojskowi na drogach ku niepodległości. Sto biogramów na stulecie Biskupstwa Polowego w Polsce, słowo wstępne Ks. bp gen. bryg. J. Guzdek Biskup Polowy Wojska Polskiego, Warszawa 2019.

Szwedo B., O. Marcin Chrostowski, dominikanin, doktor inżynier, kapelan w 1 Dywizji Pancernej, „Nasza Służba. Dwutygodnik Ordynariatu Polowego Wojska Polskiego", R. XXI: 2012, nr 10 (446), s. 11.

Szwedo B., Zawsze w pierwszej linii. Kaptani odznaczeni Orderem Virtuti Militari 1914-1921, 1939-1945, słowo wstępne Ks. Bp Gen. Dyw. Sławoj Leszek Głódź Biskup Polowy Wojska Polskiego, Warszawa 2004.

Szweycer N., Studenci pomagali studentom... „Caritas Academica” 1945-1948, [w:] Poznańscy dominikanie, Poznań 1997, s. 39-51.

Szymborski W., Sermons of Dominican Marcin Bronisław Chrostowski Delivered during World War II, „Folia historica cracoviensia”, 2020, t. 26, nr 2, s. 97-194

Szymborski W., Życie i działalność wojskowa o. Marcina Chrostowskiego uwagi wstepne, $\mathrm{w}$ druku.

Wichrowicz C. J., Stownik polskich pisarzy dominikańskich, Kraków 2012, mszps.

Zuziak J., ,Więźniowie” Sikorskiego - internowani w Cerizay, Rothesay i Tighnabruaich, „Acta Universitatis Lodziensis. Folia Historica”, 2019, t. 104, s. 167-192.

Zuziak J., Obozy izolacyjne Rothesay i Tignabruaich. Z historii Polskich Sit Zbrojnych w Wielkiej Brytanii, „Mars. Problematyka i Historia Wojskowości. Studia i Materiały", 1995, t. 3, s. 75-90.

Zuziak J., Wojsko Polskie we Francji 1939-1940. Organizacja i działania bojowe, Warszawa 2013. 